\title{
TRADE UNIONISM AND SOCIAL PROTEST MOVEMENTS IN PORTUGUESE CALL CENTRES
}

\author{
Isabel Maria Bonito Roque (D)
}

\begin{abstract}
Since the late 1980s, with the phenomenon of neoliberal globalization and the expansion of the third sector, there was an increase in the proportion of service workers, leading to a decline in the unionization rate. Portuguese trade unionism has been mainly characterized by the absence of a collective organization, not having adapted itself to the evolution of society. Therefore, trade unions face new and hard challenges concerning their organization, strategy of action, social and labor intervention with workers, trying to revive class consciousness lost to individualism. Call centres represent one of the areas which personifies the whole set of technological innovation, being considered as the fastest developing form of e-work. New social protest movements connected with digital labor have emerged in the Portuguese society, including Precários Inflexiveis, Mayday, Ferve, Precariações, Indignados and more specifically the Call Centre Workers' Trade Union. Between 2008 and 2016, forty semi-structured and biographical interviews were conducted with former and present call centre workers, trade union delegates and activists from social protest movements. This essay is aimed at analyzing how these "virtual real" social movements organize themselves and have become relevant to the "awakening" of Portuguese call centre workers' class consciousness.
\end{abstract}

\section{Introduction}

Since the late 1980s, with the growing neoliberal globalization and the emergence of new technologies of information and communication, there has been a massive expansion of the third sector, which has increased the number of service workers. This phenomena is characterized by massive lay-offs, migration, the emergence of new atypical forms of employment (part-time and temporary work, fixed term contracts, agency work, and new forms of selfemployment), a rise in average life expectancy, as well as an increase in the number of working women (Keller and Seifert 2004). In Portugal, flexible work arrangements are seen as precarious, leading to unstable employment, low wages, poor working conditions, and are deeply entwined with the erosion of the Welfare State. Nowadays trade unions face new challenges regarding their strategy and organization, leading to new types of intervention to revive class consciousness.

The proliferation of the call centre industry has often been linked to the widespread of rapid service deliveries (Mukherjee and Malhotra 2006), 
representing the fastest developing form of electronic work. Paul and Huws (2002) characterize call centres as "information processing factories" or "modern-day sweatshops," illustrated by images of call handlers "chained to cage-like workstations" by their headphones.

Since 2006, new social protest movements linked to digital labor have emerged in Portugal. Precários Inflexíveis, Mayday, Ferve, Pt Precariações, and more specifically the Call Centre Workers' Trade Union, are some of the examples of "virtual-real" activism, working as powerful weapons at the service of media activists to support their struggles (Ribeiro 2000; Waterman 2002). Just as alternative media activists in the late 1960s and 1970s incorporated video technologies, nowadays the new social protest movements, especially the Call Centre Workers' Trade Union, communicate and disseminate their messages mainly through social media and digital technologies (Edwards 2001).

In this article I analyze how these novel social movements organize themselves and became relevant for the "awakening" of a class consciousness of call centre workers who are fighting for their rights, as well as their importance for the Portuguese society and precarious workers in general. Between 2008 and 2016, forty semi-structured and biographical interviews were conducted with former and present call centre workers, as well as with trade union delegates and activists from social protest movements. The majority of the interviewees were highly educated people, mostly women, with ages ranging between thirty and fifty-four years old. Most of them were still working in call centres, while others had already left, were dismissed, or were living abroad, looking for better life opportunities. Finding interviewees was a relatively easy task since the author had already worked in several Portuguese call centres, and has been involved in social protest movements and trade unions, and various informants were also identified through snowball sampling. From the qualitative analysis of the interviews and through informal conversations, it was concluded that by 2014 the majority of the interviewees were not unionized and did not participate in social protest movements. Instead, they were living in fear, submitted to logics of consent and resignation, creating fragmented, isolated, fragile and alienated identities, leading to a reduced participation in social and economic life. The informants justified this phenomenon due to the fact that working in call centres was something they perceived as transient while they were looking for better working conditions. In this sense, unionizing would not be a risk worth taking, especially due to the possibility of moral harassment or wage loss (Roque 2010).

Through exploring the interviews, the following chapters will describe and analyze the global economic and social scenario underlying the emergence of call centres in Portugal, the profile of call centre workers, as well as the particularities of the trade unions and social protest movements involved in this sector. In a society where the trade union force is weakened and new social protest movements have been rising since 2011, a special emphasis will be given to cyberactivism enhanced through the Call Centre Workers' Trade Union and through Precários Inflexíveis, a social protest platform. The poor call centre workers' representativeness leads to the loss of labor rights, especially in a sector where specific legislation 
is very scarce. Besides creating vulnerability between workers, where they can be easily dismissed, it can also lead to serious psychosocial risks as we will discuss on the present article.

\section{Call Centres}

The digital revolution of the twenty-first century transformed work, now enacted in networks and in constant connection. In this sense, new technologies of information and communication were disseminated, bringing new challenges for the world of labor, including social, economic, and technological dimensions and involving many advanced economies (OECD 1998). The digital revolution also encouraged qualification, mobility, and flexibility, leading to a knowledge society focused on the production and exchange of knowledge in a continuous learning process. New Toyotist and post-Taylorist production models were implemented, based on flexible organizational structures and networks, appealing to a sense of initiative, autonomy, and versatility, as well as a new labor relationship of self-employment and the replacement of the employee by afterhours timetable service providers (Kovács 2002). Tertiarization, feminization, and the dissemination of flexible forms of employment are significant trends in the recent evolution of employment in Europe. The development of the service sector allowed professions associated with the branches of telecommunications, environmental engineering and informatics to be identified as professions of the future (Kovács and Casaca 2004).

Since the 1990s call centres became the best bet for companies from any field, especially in the promotion of their service areas or customer support with the lowest costs involved (Burgess and Connell 2006; Taylor and Bain 2007, $355)$, meaning the tailoring of intellectual work and services field work. The scenarios of technological innovation are personified through a timed rationalization of work (Castells 1996) and the employment of salaried precariats (Paugam 2000). According to Braga (2006), there is an imprisonment of the spiritual work force and its practical knowledge in a production routine marked by work interaction of labor with information technologies.

Call centres are excellent illustrations of the relationship between twentyfirst century technologies and nineteenth century labor conditions, submitting the worker to Toyotist flexibility and control techniques stemming from Taylorism (Antunes and Braga 2009). Though labor flexibility affects every economic sector, it is in companies like call centres that workers are more exploited.

Call centres are a symbol of the modern service economy where services are available all around the clock, being delivered from almost any spot (Paul and Huws 2002). Within the neoliberal system, these companies engage in forms of outsourcing to foreign countries where costs are lower and labor is much cheaper. The location of call centres varies widely in different parts of the world, reflecting diversities in terms of technology and culture (Bonnet 2002). There are also different kinds of call centre services which provide information to callers, connect consumers to third parties, sell goods/products/services over the telephone and supply 
emergency services and helplines (Glucksmann 2004, 254). In this sense, there are call centres which are exclusively focused on the inbound service and there are others which comprehend both inbound and outbound services, receiving or transmitting a large number of requests by telephone, e-mail, and chat.

According to the Portuguese Society of Contact Centres, ${ }^{1}$ Portugal is on the radar and agenda of international decision makers in attracting foreign investments for the installation of call centres. Portugal is strategically positioned on the intercontinental routes that present the best technological infrastructures. According to the President of the Call Centre Workers' Trade Union, Danilo Moreira, the telecommunications call centres, and the inbound service in Portugal represent around 70 percent of the calls operated by call centres and the workers' profiles have change:

In the late nineties, when I started working in call centres, there were more women and students with a part-time job. With the emergence of call centre lines related with banks, and technical lines dealing with technologies of information and communication, more men were hired. With the 2008 crisis, the age group became older as a consequence of dismissals and company closures forcing people to face new realities and new means of life. Nowadays we also see mostly people with 30 and 40 years of age, but also unemployed people with 50 and more, some of them working in part-time regime in call centres as an addition to their basic pension.

The expansion of the call centre "complex" has been characterized by a focus on the clients, the quality of products and services, technological innovation, and various strategies for organizational rationalization, including subcontracting and outsourcing (Casaca 2006). Call centre companies, mainly through temporary work agencies, tend to offer short-term contracts which allow workers to be easily dismissed or seasonally replaced by others more profitable to the company. In this sense, the social and working life of the individuals is rendered unstable, flexible, and precarious. This scenario reinforces individualism, decreasing trade union membership and the weakening of professional and social bonds (Sennett 2001).

\section{The Call Centre Worker}

The call centre workers are knowledge workers (Drucker 1959) who perform abstract/immaterial work (Marx 1990). They organize and redirect information, performing the virtual delivery of products, keeping, and managing the relationship between capital and the service sector clients. The existence of these workers is characterized by a number of gestures and tasks that prevent them from developing their mental capabilities and potential, being a mere extension of the computer, leading to a total absence of passion and autonomy at work. To sell more products and/or services and to secure customer loyalty, workers practically ignore all verbal forms of aggression, always smiling down the phone through the use of their voices (Callaghan and Thompson 2000; Hochschild 1983; Roque 2016; Taylor and Tyler 2000; Taylor et al. 2002). Apart from speaking with customers, the worker has to 
be able to register, in a virtual application, all the actions undertaken during the call, being also responsible for software development, electronic file updating and the delivery of tasks related to the telephone operator. In this sense, telephone technology is articulated with new technologies which integrate computers and telephones, customized for particular functions (Glucksmann 2004).

Inside the call centre, the worker is restrained to a small cubicle in a room, having access to a shared keyboard, a chair, headset and mouse; the space is not properly cleaned and the room temperature is often inadequate. The operator has also to be fast, attentive, friendly, emotionally balanced, and flexible, that is, being able to deal with unexpected situations. The training is very occasional, mostly virtual, and in the attendance position. The working teams are formed by twenty to thirty workers and managed by one supervisor. There are also occasions of moral, sexual, gender, and racial harassment, where, most of the times, female workers are screamed at. Career progression is very scarce or even null, and being a supervisor is the highest position that these workers might achieve. According to Brophy (2009), the neotaylorist mode of production provides the workers with low wages, high stress, precarious employment, rigid management, draining emotional labor, and pervasive electronic surveillance.

Taylor and Bain (1999) have identified the contradiction between the quantitative and qualitative dimensions of the labor process in call centres, which cannot be resolved, creating an assembly-line inside the workers' head. According to the authors, call centre companies demand that tasks (answering the calls) must be carried out by workers in the shortest time possible (quantitative dimension) with the maximum quality (qualitative dimension). This is a paradox in the sense that the higher the quantity of calls the lower the quality of service, for the levels of stress and emotional exhaustion will be extremely high, leading to vulnerabilization. The workers' identity is deconstructed, in the sense that they feel unable to identify with the role of call centre operators, preventing them from achieving a professional career or attaining a sense of belonging to the company (Huws 2003). A process of subjectification takes place, generating a "cybernetic personality" (Roque 2016), a disconnect between work and professional and educational skills, resulting in a process of "status discord," that is, disqualification (Kosugi 2008).

Temporary work agencies establish short-term relationships with call centre workers, submitting them to flexible and uncertain working conditions. In this sense, they form the growing army of the precariat, a symbol of globalization, electronic life, and alienated work. These individuals perform unsafe work, incapable of giving them an occupational identity or desired career (Standing 2011, 15). They are seen as the "new proletariat of modern times" (Scott 1994, 236) of the service sector, being characterized by few opportunities for training and professional development, low salaries, and a tremendous vulnerability to labor precarity (Casaca 2005).

Nowadays, the majority of people view call centres as representing real work, and not a transient occupation while they complete their studies. As time goes by, they remain in these companies, undermining their life plans. Since it is their only source of income, they are driven by a sense of fear. Even though no 
one's ambition is to work as a Call Centre Operator, even if there is no sense of identification, workers end up staying for many years working in call centres (Huws 2014). In Portugal, this occupation is not recognized as a profession. It is characterized by low union membership rates, since these workers do not organize themselves around occupational identities. To support everything that has been described, I present relevant excerpts from the interviewees:

I use to say that the street sweeper and the cleaning lady have a profession, they are workers from somewhere and dedicate themselves to cleaning. A call centre assistant doesn't have a profession, a career, only works at a call centre. I think nobody there feels that he/she has a profession. What is it? I work in a call centre, I am nothing, there's no identity. Career, I don't think they even think about it. There is no notion of what a professional career is.

I'm not happy at all with the work that I do. With the passing of the years we get conformed or even try to think, with a good mood on, that the day will go on faster, but at a professional level this isn't a stimulating work. The main feeling is that we are cannon fodder. We're just a mere number inside the call centre. There are no names, just statistics inside the company. If he/she doesn't work, another one will come along.

\section{Portuguese Trade Unionism}

The trade union movement arrived quite late in Portugal, being established with the democratic revolution of April 25, 1974, the so-called Carnation Revolution. This process radically changed the social and political scene and paved the way to the emergence of social movements inspired by left-wing parties, such as the Portuguese Communist Party. In 1972, the biggest Portuguese trade union force, CGTP-Intersindical (General Confederation of Portuguese Workers National Trades Union) and UGT (General Workers' Union), joined the political scene. UGT was identified as a reformist trade union, linked to the center and right wing political parties, PS (Socialist Party) and PSD (Social Democracy Party), and was considered as a privileged partner for social dialogue (Estanque 2005). CGTP-Intersindical was always connected to the left-wing parties.

By the end of the 1980s, with the neoliberal globalization and the expansion of the third sector, the service class grew to the detriment of the working class, leading to a decrease in the unionization rates (Ibid 2005). Progressively, trade unions lost touch with labor reality, ignoring the degrading conditions of the vulnerable and disqualified workforce. The majority of trade unions became bureaucratized, working like large corporations, dominated by leaders and boards, working on a professional basis and treating their employees in an unequal manner, ignoring the precarious situation that the most vulnerable and disqualified masses of the workforce lived in (Estanque 2010, 10-11; Pannekoek 1934).

Trade unions became more active in institutional regulation, negotiating with the State and other social partners, changing its scope of action and 
becoming mere instruments of regulatory action of the State (Estanque and Ferreira 2002). Nevertheless, its main weakness relies on the inability to deal with atypical working conditions, prompted by service companies such as call centres; the unstable, flexible, and precarious working conditions which reinforce individualism, decreasing trade union membership and weakening professional and social bonds; and the lack of credibility and representativeness of trade unions among precarious unorganized workers as a consequence of its political involvement. In sum, there isn't the ability to organize and represent the emergent precarious workforce (Brophy 2017). According to the President of the Call Centre Workers' Trade Union, the true role of trade unions, linked to the defense and support of workers' struggles, has been undermined. The strong influence of political parties does not allow them to adjust their ideologies and modes of action to the current Portuguese context.

\section{Portuguese Call Centre Trade Unions}

This section will present the most relevant trade unions in Portugal related to the call centre and telecommunications sector.

The South and Islands Electric Industries' Trade Union (SIESI) (figure 1) stems from the former electricians' trade union and it is affiliated with CGTPIntersindical. It is linked to the EDP (Electricity of Portugal) call centres and its foundation goes back to 1939, the beginning of the Electricians' National Trade Union. The main goal of this trade union is to avoid temporary agency companies from employing EDP call centre workers, allowing them instead to be part of the company. Recognizing the role of call centre workers as a profession is not the union's main goal, and it refuses to work with other trade unions around this demand. According to one of its affiliates, this trade union has political connections and strikes are usually called by EDP workers.

The National Trade Union of Postal and Telecommunication Workers (SNTCT) (figure 2) was created with more than 10,000 workers of the Postal and Telecommunications Public Company of Portugal, on March 5, 1974 in Lisbon. SNTCT aims at protecting and enhancing the rights and benefits of

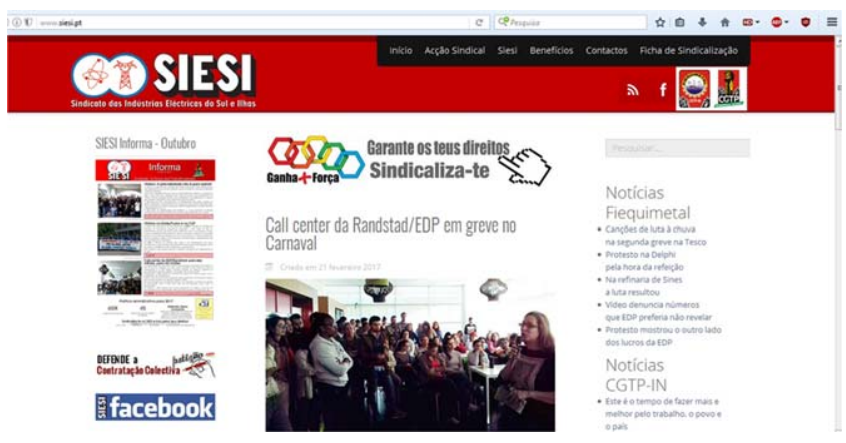

Figure 1. Siesi Webpage.

Source: http://www.siesi.pt/ 


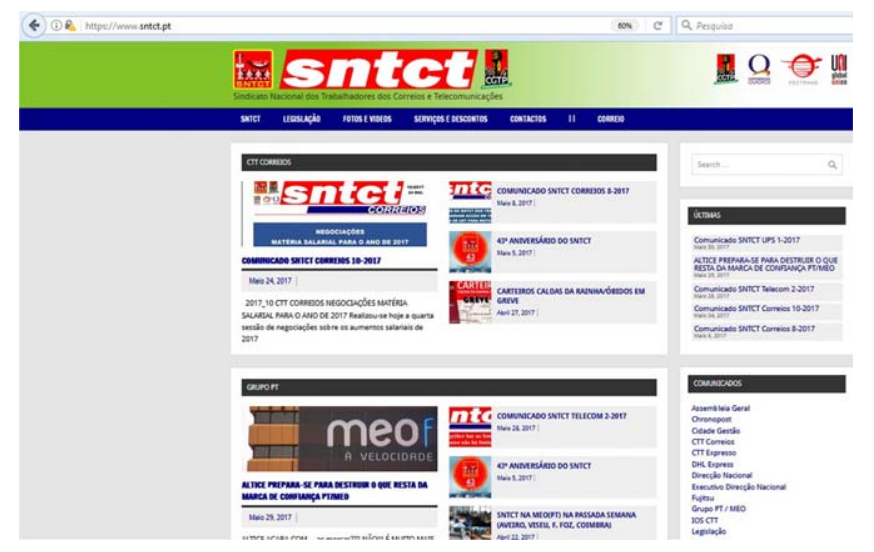

Figure 2. SNTCT Webpage.

Source: https://www.sntct.pt/

postal and telecommunications workers. This trade union appeals to everyone who works in companies, societies, institutions, and State organisms related to communications and telecommunications. Their last action was for wage increases for UPS (United Parcel Service) workers, in January 2017, and for Postal workers, in May 2017. Like the majority of trade unions, they offer special discounts for unionization.

SINDETELCO is the Democratic Union of Media and Communication Workers, (figure 3) representing postal, telecommunications, graphics, logistics, and new economy workers. It was created in 1981 and it is affiliated with CGTP. According to one of the interviewees, at the beginning of each year SINTTAV visits several call centres and distributes various calendars, as well as forms for prospective union membership. Sometimes they reunite with workers in plenary debates-the last one took place in 2013. According to a call centre worker, when someone presented a difficult situation, such as being fired or suffering moral harassment, they provided limited legal support.

The National Trade Union of Telecommunications and Audiovisual (SINTTAV) (figure 4) was created in 2006 and it is affiliated with UGT.

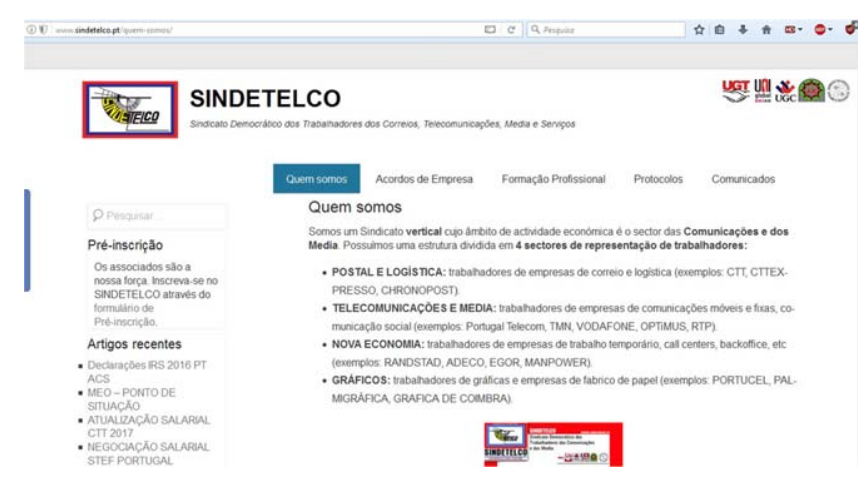

Figure 3. SINDETELCO Webpage.

Source: http://www.sindetelco.pt/ 


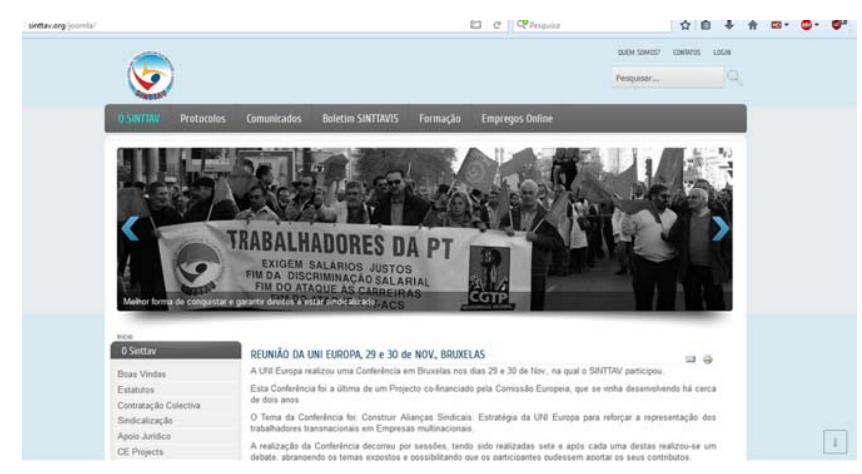

Figure 4. SINTTAV Webpage.

Source: http://sinttav.org/joomla/

According to the interviewees, occasionally its representatives visit call centres, mostly to offer special discounts to new affiliates through their training courses. Every month they organize a discussion meeting even though they reveal very limited knowledge of what actually happens in the field.

Pt Precariacções was a social protest movement of the telecommunications sector which had its roots among call centre workers in Coimbra. Between 2006 and 2013, their actions comprised the distribution of flyers and the development of a blog (figure 5). It had seasonal but anonymous manifestations in the public realm to save the workers' integrity from possible retaliations from the employers. It was formed by twenty call centre workers from Coimbra and Porto and they also struggled for better working conditions and an increasing public awareness. This social protest movement aims at drawing attention to the human atrocities that call centre workers are exposed to.

Figures 6 and 7 show a number of flags that were placed in front of the main call centre in Coimbra, in 2009. The board called the police and they showed up immediately to arrest the workers who had committed these actions. According to an interview given by a trade union delegate from SINTTAV, who was also a founding member of this movement, the Telecommunications' Trade Union sector was in a state of apathy and conformity. This led to a "rebellion" and a feeling of discontent experienced by workers who rely on very low wages. The members of this social protest movement later on went to Lisbon, Braga, and Porto, distributing flyers and reuniting frequently in plenary debates. In 2014 they decided to formalize their struggle, creating the Call Centre Workers' Trade Union (STCC).

The STTC (figure 8) was formed in Lisbon, in August 2014, being the result of "virtual-real" activism and interaction, mainly with the workers who previously were members of PT Precariacções.

The first President of the Call Centre Workers' Trade Union was Paula Lopes, a forty-year-old woman, who told me that it all started in August 2013 with the social protest movement Pt Precariacções. At the entrance of Braga and Coimbra call centres, the workers were involved in the social protest movement 

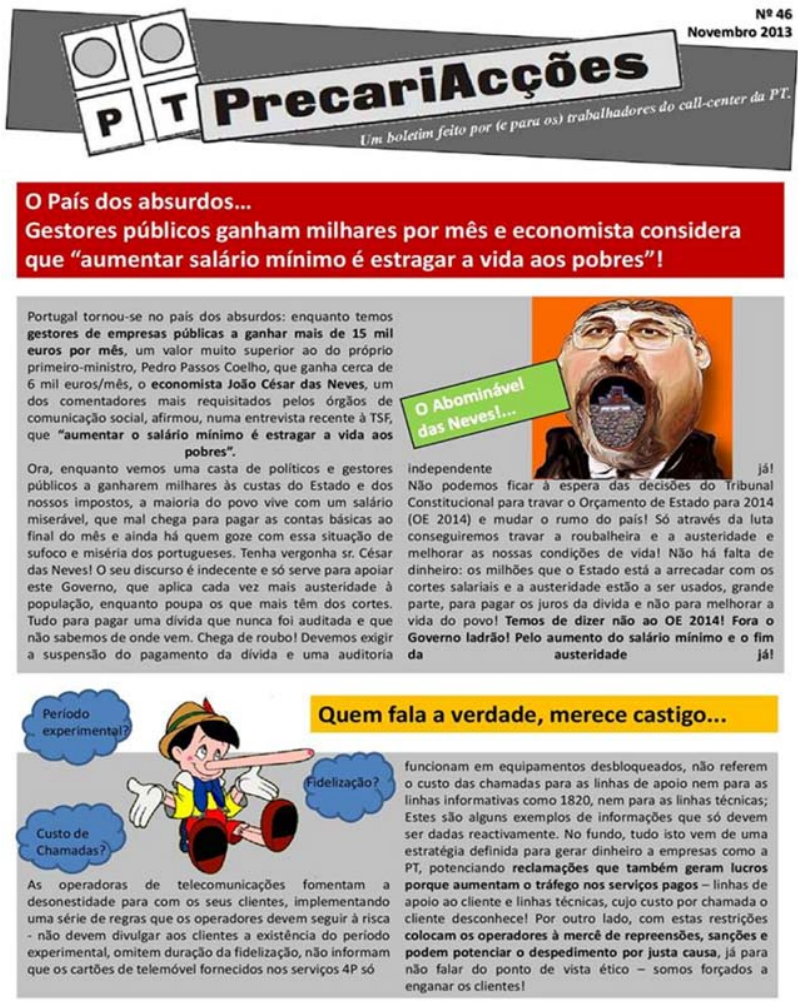

Figure 5. PtPrecariacções Flyer.

Source: http://ptprecariaccoes.blogspot.pt/

distributing bulletins (figure 9) that denounced the precarious situations they experienced. Later on the movement was expanded to Lisbon, organizing some meetings with the "Tás Logado" group, debating ideas for the creation of a new trade union. Although these meetings always took place in Lisbon, the workers were in touch with members from Coimbra and Braga. In September 2014, the

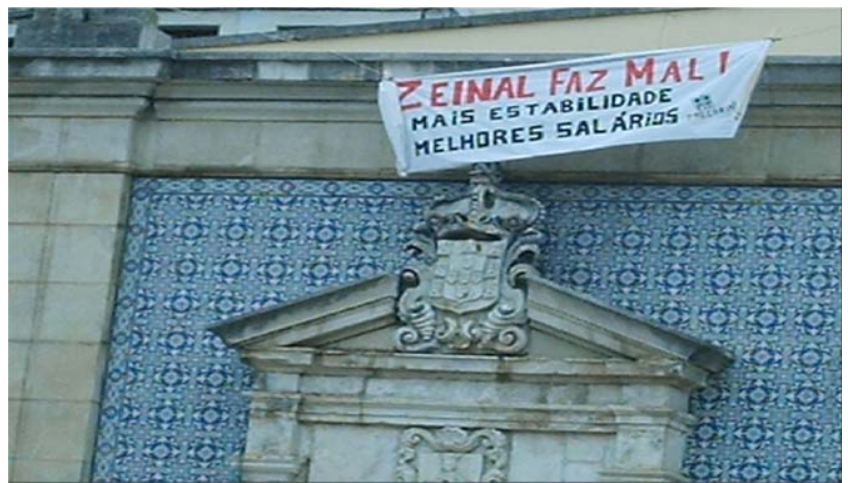

Figure 6. Photo of Precariacções Public Manifestations.

Source: Photo taken by the author, July, 2009 


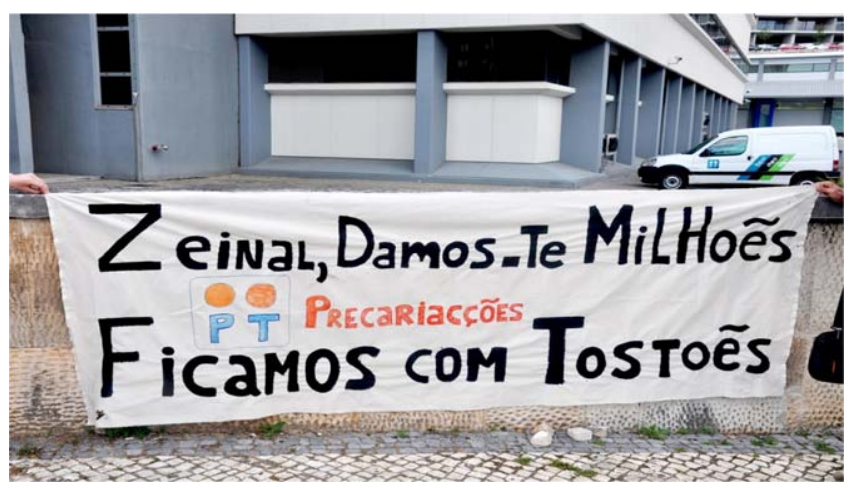

Figure 7. Photo of Precariacções Public Manifestations. Source: Photo taken by the author, July, 2009

statutes were published by the Installing Committee, constituted by call centre workers who worked for free. In 2015, due to extreme exhaustion, Paula decided to step back and a new President Danilo Moreira, a forty-year-old male, was elected for the presidency, offering his valuable experience of working in several call centres for twenty years as supervisor, operator and quality technician. In the next section, the role of this trade union will be explained in detail, as it can be considered as a new form of union struggle, that is, cyberactivism.

\section{Portuguese Call Centre Cyberactivism}

Cyberactivism dynamics were extremely relevant for the processes of dissemination, organization, and mobilization of social protest movements in Portugal. Among call centre cyberativism, STCC operates through a website, a blog (figure 10) and a Facebook page named "Tás Logado." Through these virtual platforms call centre workers can pose their labor and legal questions, interact with the leaders and delegates and also collect information on labor rights and trade union activities. STCC's range of action is broadened and open to

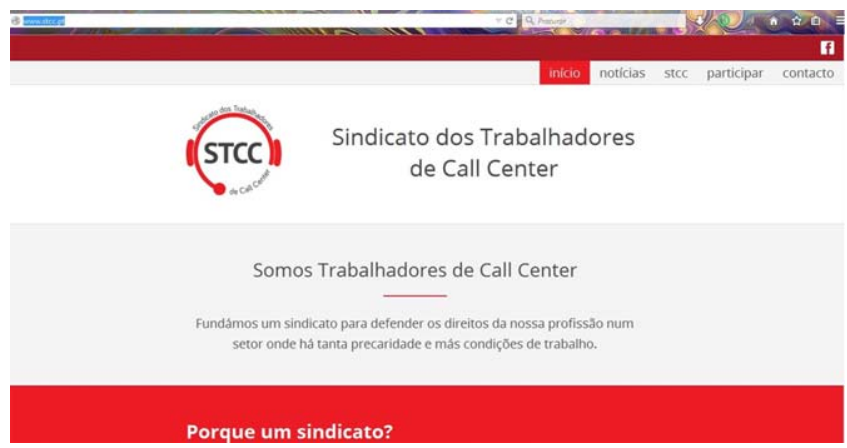

Figure 8. Call Centre Workers' Trade Union Webpage. Source: http://www.stcc.pt/ 

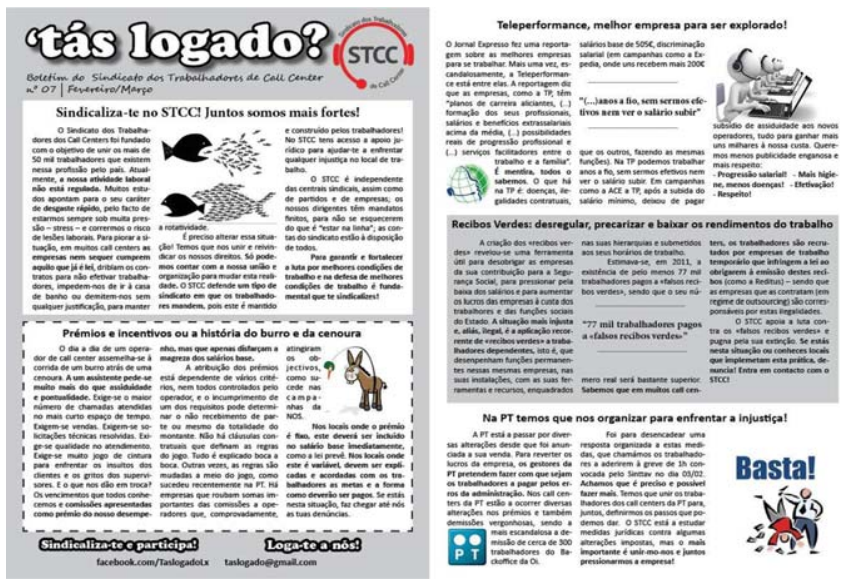

Figure 9. Call Centre Workers' Trade Union Flyer.

Source: https://www.facebook.com/TasLogadoLx

cooperate with society, namely with other trade unions, social movements, and even with various political parties at the national and international levels. They frequently organize plenary debates to revive the notion of collective and juridical support. Besides the official trade union e-mail, they also operate through Facebook chat and messages and, more recently, they have created a mobile help line which is reachable even on weekends. Nevertheless, face to face and e-mail contacts are the preferred means of communication, mainly because workers recognize the delegates from flyers distribution at the entrance of call centres or from their appearance in the media. In this sense, it gets easier to contact them. In the vast majority of the cases, anonymity is required and the Call Centre Workers' Trade Union only acts in the field after the worker gives his/her approval. Sometimes, legal support is required and frequent meetings take place for negotiation with the companies.

One of the main goals of the Call Centre Workers' Trade Union is the approval of a petition (figure 11), submitted on the October 12, 2016, to the

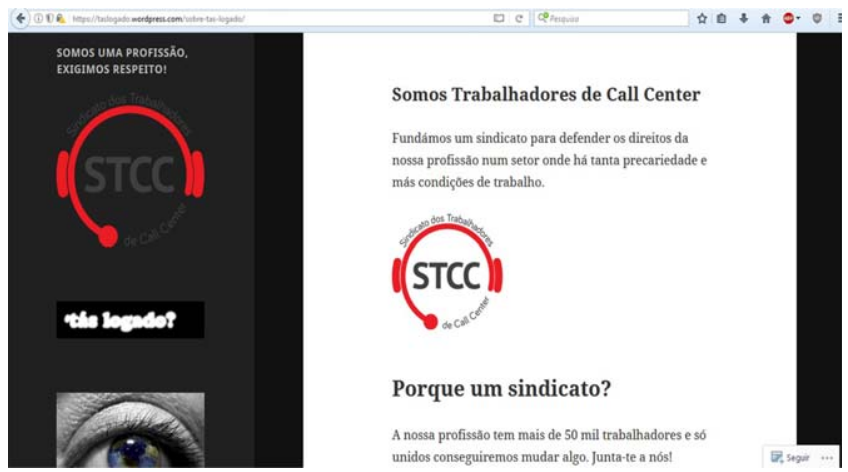

Figure 10. Call Centre Workers' Trade Union Blog . Source: https://taslogado.wordpress.com/sobre-tas-logado/ 


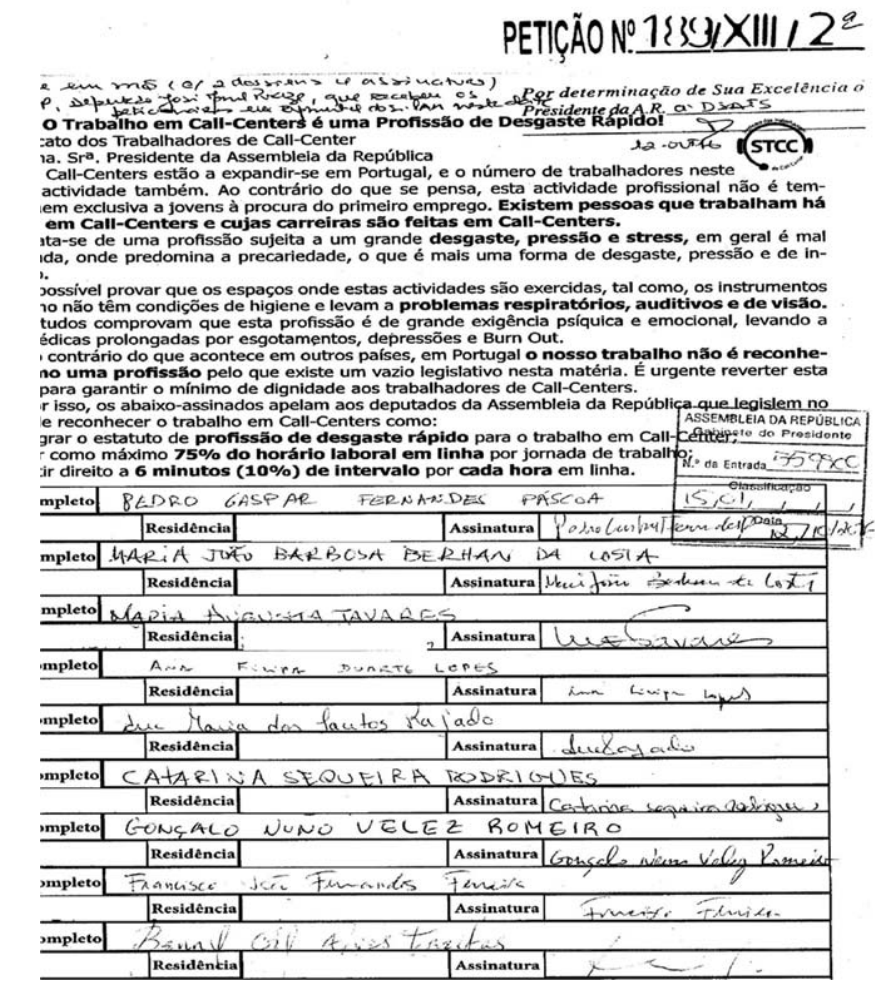

Figure 11. Call Centre Workers' Trade Union Petition submitted to the Portuguese Parliament. Source: Petition from the Call Centre Workers' Trade Union

Portuguese Parliament. For that they submitted an electronic petition (E-petition), aiming the recognition of the call centre worker's role as a "high stress occupation" and as a profession recognized by the Standard Classification of Occupations. To avoid excessive stress and fatigue, due to the frenetic call answering line, they also demand that the work conducted in call centres should be 75 percent online and 25 percent back-office.

This trade union is also involved in struggles against moral, gender, racial, and sexual harassment and with the women's and nationality social movements. Due to the fact that the biggest complaints are within the psychological realm, depression and burnout situations often reported. As an interviewee stated:

Psychological support we don't have at all. More often we see customer relationship assistants taking a sick leave for exhaustion and psychological fatigue reasons. More and more they demand from us. What they pay doesn't correspond to what they require.

In this sense, STCC aims at creating a multidisciplinary team to deliver psychological support to workers, with the help of call centre operators who are also specialized in Hygiene and Safety at Work and in Psychology. 


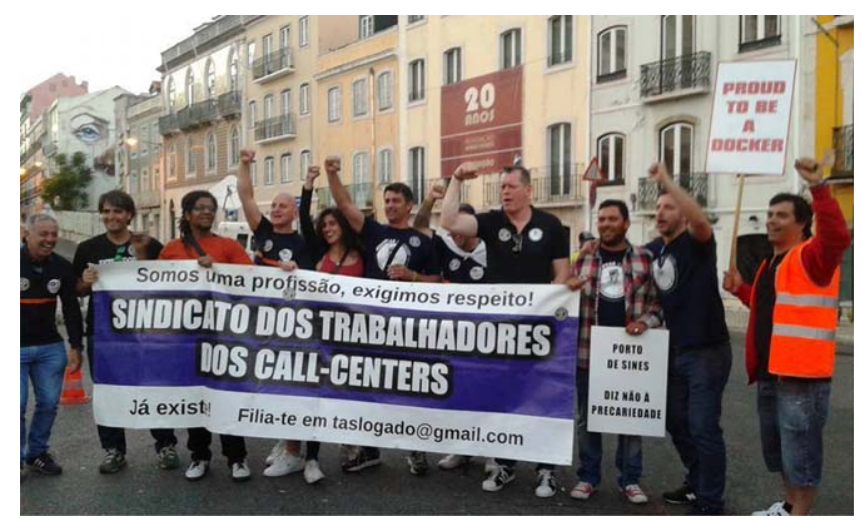

Figure 12. Call Centre Workers' Trade Union Strike. Source: Call Centre Workers' Trade Union

What distinguishes this call centre trade union from the others is the fact that its members are present call centre workers, which gives them a real notion of what happens in the field, being also able to receive a bigger recognition by the workers since they have a greater awareness of these topics, and deal with this reality on a daily basis. This trade union is also not attached to any central union, nor political parties, providing a higher degree of freedom to engage in parallel activities with other trade unions, strikes, and social protest demonstrations and movements that might not be directly related to call centres but that can offer the exchange of experiences among precarious workers.

A good example of this exchange of experiences was the participation in the Dockers' trade union strike (figure 12), held in May 2017, where STCC got involved not only in cyberspace but also participating in the field. This was an experience that also involved academics involved with this matter and the wider society, to share experiences and bring more people into activism.

At the present moment, the STCC has eight delegates across Portugal located in the major call centres in the north and center of Portugal. The vast majority of call centre workers are people who frequently use the internet and are familiar with social networks. The internet allows STCC's message to reach a wider audience, traveling through the cyberspace and becoming the main tool for action. The Blog is also very dynamic, being especially built on the Wordpress search engine, allowing it to be on the top of web searches. Instagram and Google + are also used, and the latter is directly connected with YouTube, where they often upload videos stemming from their conferences and social demonstrations, trying to reach people who are more "visual."

The Call Centre Workers' Trade Union faces many challenges and also aims at continuing to collaborate with Precários Inflexíveis, sharing synergies and struggles, and also with call centre workers in Brazil, Poland, and Spain who are trying to create a similar trade union with the same cyberspace strategies. Their goals also include raising the number of associates and to stimulate them into action; to consolidate the bonds between the media, legal authorities, and 
other call centre trade unions, as well as with workers' commissions and active social movements fighting precarity; to reinforce the virtual social networks among the public; to support the development of academic studies on call centres; to reinforce partnerships at the international level, especially in Brazil and Europe; to begin a process of collective negotiation with companies; to continue providing face to face and online legal support at the national level; to create partnerships with services which offer value to their associates; to revise STCC's statutes and to intensify plenary debates with companies, including board members and workers; and to strengthen the role of the union delegates.

\section{New Social Movements}

From the end of the 1960s we have witnessed the emergence of new collective action and social movements, with significant impacts on cultural and political fields, mainly associated with youth cultures and "middle class radicalism" (Butler and Savage 1995; Eder 1993; Esping-Andersen 1993; Estanque 2010; Melucci 1996; Parkin 1968; Touraine 1969). New social movements (NSMs) led to new forms of activism and public intervention, mainly in the political arena. They are quite different from the old social movements and political parties, playing a role that trade unionism could not achieve due to a new discourse and a more democratic agenda. These new movements of social protest were led by radical youth politicians from the middle class who organized themselves in flexible and ad hoc ways, that is, forms of spontaneous and ephemeral leadership. They were stimulated by a wider social segmentation, especially by young educated people who dreamed about changing the world and the system (Estanque 2005; Eyerman and Jamison 1991; Habermas 1998; Touraine 1994). They fought globally and acted locally, generating spectacular forms of action in the public realm, attracting the attention of mass media. Even though their political, social, and cultural impact was strong, they did not define any long term political strategy. It was a generational counter culture movement which obeyed a sporadic logic which repeated itself in the society in many ways (Estanque 2005, 8).

In 1974, with the Carnation Revolution, a vast number of citizens were engaged in social struggles and the revolutionary political climate was tremendously intense. Trade unionism, political action, and popular movements merged, being almost impossible to recognize them as separate entities. At the international level, this Portuguese revolution was seen by many as an expression of the new social movements (NMSs), even leading to the possibility of building a model of participatory democracy. Nevertheless, the radical Left Parties and the Communist Party advocated a "dictatorship of the proletariat" in the sense of a dialectical rapprochement between new and old social movements. The new social protest movements are considered as alter-globalization movements, following the Seattle example, for their extraordinary capacity of "virtual-real" activism and the use of the internet and cyberspace for access and information broadening. Though this could be a tremendous weapon at the service of the union movement (Ribeiro 2000; Waterman 2002), many authors argue that these social movements cannot be considered as such, for a social 


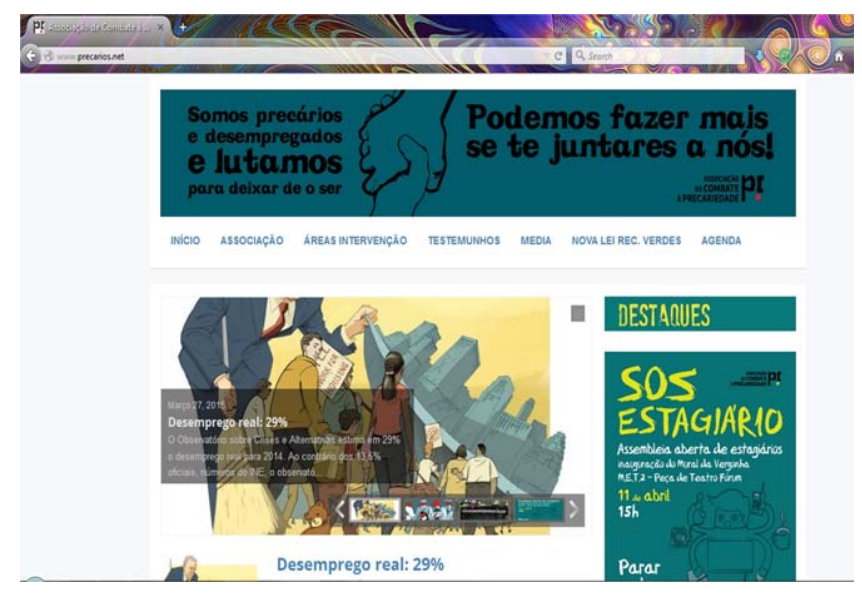

Figure 13. Precários Inflexíveis Webpage. Source: http://www.precarios.net/

movement only exists when a certain collective fight follows the principles of a collective identity of "class" or a feeling of belonging, usually manifested in the opposition to a common enemy or target, as well as in the identification with wider social goals (Dibben 2004; Touraine 1984).

\section{"Precários Inflexíveis-Association for Precarity Struggle"}

Apart from STCC, Precários Inflexíveis can be seen as a prime example taken of these new social protest movements, being as well as one of the most relevant cyber support platforms in Portugal. It was the first cyberactivist platform organizing with a website (figure 13), a blog, and a Facebook page aiming at helping precarious workers and trade unions. It was created in 2013 with former members of other social protest movements, like Mayday and Ferve (green receipts contracts) movements, and also with young graduates, in its majority affiliated in the Left Bloc Party. Their headquarters are located in Lisbon and they work with a cultural and political agenda.

Anyone can join this platform, and they often gather in several workgroups such as Green Receipts, Temporary Work Agencies, Research Assistants, Social Security, and Call Centres. They also elaborate newsletters and flyers and on the cyberspace they have a website and a Facebook page. On the streets, they hand flyers to the workers and participate in social protest demonstrations and strikes. Above all, their major aim is to inform workers and unemployed people about their labor and civic rights but also to participate in social protest demonstrations and strikes.

Throughout the years, this social movement has been deeply connected with the call centre struggle, especially in 2013 with the mass layoff of nurses from the Saúde 24 call centre service (figure 14). 


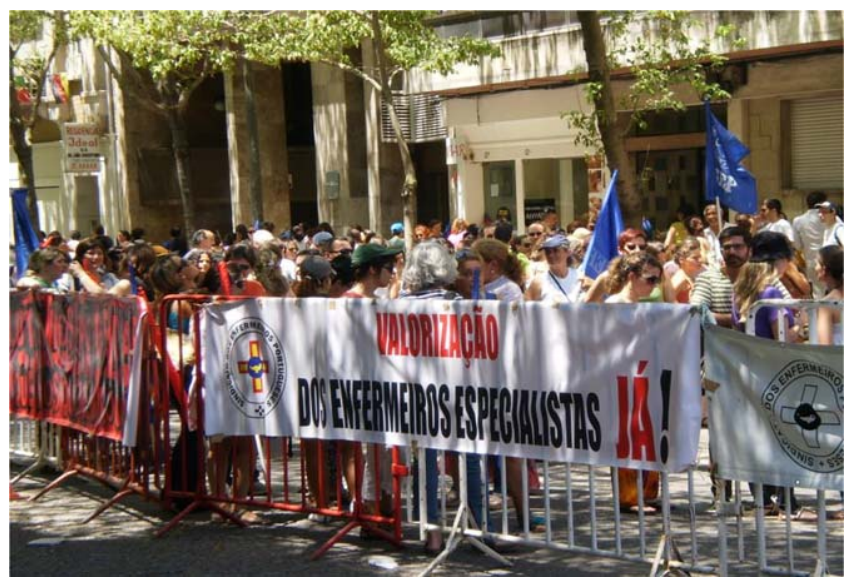

Figure 14. Saúde 24 Call Centre Workers' Strike with the support of Precarios Inflexíveis. Source: https://www.facebook.com/precariosinflexiveis/

\section{Conclusion}

Through the analysis of the interviews, some fundamental features of call centre employment are evident, including the deconstruction of an occupational identity and the lack of expectations, generating feelings of alienation and frustration. The majority of the interviewees were women, aged between thirty and forty years old, who reported high levels of stress, alienation, unhappiness with the daily routine and with their contractual situation, as well as lack of fulfillment and recognition by the company. In this sense, they were highly dependent on antidepressants. The humanitarian and altruistic aspects were mentioned as the only positive dimensions of call centre work.

In this sense, we can see that there is much work to be done concerning call centre workers' rights. The Call Centre Workers' Trade Union was the first in Portugal to deal specifically with problems related to call centre workers, namely bullying, safety and hygiene conditions, and dismissals. They also engaged in producing a specific legislation for this sector. The majority of interviewees also reported that when they began working in call centres, they did not believe in the role of trade unions. Nevertheless, since the appearance of STCC their struggle attained public visibility and more workers became unionized.

Regarding the traditional role of trade unions, there is still some disbelief among workers, as well as a sense of fear in affiliating. From the interviews conducted through the elaboration of the present article, disappointment and misbelieve in the traditional trade unions are very present, quoting:

My colleagues and I were motivated to join a trade union to do something regarding our problems. Since I was a socially active person, I was a member of Precários Inflexíveis, I wanted to be part of a change and help my colleagues. In this sense, I managed to get a meeting with the vice-president of Sinttav Trade Union, where I was affiliated. When I spoke with him, it 
was like I was talking about something that he knew nothing about. We received no information about the changes in the labor code, about the strikes. Me and my colleagues started questioning the reason for this affiliation, the reason for giving them part of our salaries every month and not seeing any practical help and information.

The global labor market undermines the work of trade unions and their efforts are insufficient to respond to the twenty-first century labor demands. The abrogation of the tripartite collective bargaining between the hiring parts and temporary work agencies jeopardizes the possibility of negotiation. In this sense, trade unions must accept the challenges from new international dynamics and alliances as a condition to revive trade unionism in a globalized capitalism and international sense of action (Estanque 2005, 133; Waterman 2002). This is the reason why the social models of struggle undertaken by the Call Centre Workers' Trade Union are so relevant, in the sense that they engage with other national and international social movements and trade unions. A good example of this situation is the support given to the Dockers' Trade Union, as well as to the Women's movement, the Nationality movement, their involvement with Precários Inflexíveis, their support to the Spanish, Polish, and Brazilian Workers' Commissions, their involvement with other trade unions and call centre strikes, but also their support to Academia and investigators. In this sense, the media and academia have displayed a growing interest in call centres and call centre workers, analyzing their specificities, in particular their modus operandi. Gathering the call centre world, the media, academia and the workers in a "social agora," creates synergies between them, generating new forms of global activism and organization, connected with labor and other human and environmental struggles, through the use of new technologies of information and communication (Waterman 2002).

Nowadays, the majority of the Portuguese population does not believe in the efficacy of political participation in activist groups and demonstrations in particular are disapproved of by many Portuguese workers. This poses serious questions for civil society groups where new activists cannot be recruited easily through personal networks (Baumgarten 2013; Pinto et al. 2012). STCC has a particular aptitude for action, that is, it is a call centre trade union which operates mainly through cyberactivism on social media but is also present in social mobilizations or when a worker reports a problem or specific issues which need to gain visibility within companies and within the wider society. According to a delegate, it was noticeable that this leads to a contagious behavior, where the other trade unions started to worry much more about the workers' rights and their flyers started to focus more on precarity and unionization than they did before. They also started publishing more information on call and contact centre matters and calling for strikes, as happened on June 30, 2017, with SNTCT and CGTP-Intersindical demanding a rise in salaries and permanent contracts. STCC's involvement is not only virtual but this trade union is also present on the streets with other social protest movements and trade unions. 
In this article I summarized the main points and the lessons we can take from the new social protest movements, especially in the Portuguese case, which are already changing and alerting the society for the precarious workers' situation. They are progressively obtaining media and government attention, displaying a strong impact at the international level, establishing associations with other Brazilian and European trade unions, as well as precarious workers' movements. In the twenty-first century, a combative, democratic, open, and independent trade unionism is highly needed.

Isabel Maria Bonito Roque is a PhD Candidate, Sociology, Labor Relations, Social Inequalities and Trade Unionism at Faculty of Economics, Coimbra University. E-mail: isabelroque@ces.uc.pt.

\section{Notes}

This paper is the result of crucial collaborations from Danilo Moreira and Manuel Afonso, from the Call Centre Workers Trade Union, from Precários Inflexíveis members and also from all the interviewed workers and friends from Portuguese call and contact centres.

1. http://www.apcontactcenters.org/

\section{References}

Antunes, R., and R. Braga. (orgs). 2009. Infoproletários: degradação real do trabalho virtual. São Paulo: Boitempo.

Baumgarten, B. 2013. Geração à Rasca and beyond. Mobilizations in Portugal after 12 March 2011. Current Sociology 61 (4):457-73.

Bonnet, N. 2002. The establishment of call centres in France: Between globalism and local geographical disparateness. NETCOM 16:75-8.

Braga, R. 2006. Nossa herança (info)taylorista: aspetos da degradação do trabalho e da relação de serviço em centrais de tele-atividades. In Revista Brasileira de Saúde Ocupacional. São Paulo: 133-152.

Brophy, E. 2009. Resisting call centre work: The Aliant strike and convergent unionism in Canada. Work Organisation, Labour and Globalisation 3 (1):80-99.

- 2017. Language put to work. The making of the global call centre workforce. Palgrave Macmillan. UK

Burgess, J., and J. Connell. 2006. Developments in the call center industry. Analysis, changes and challenges. New York, NY: Routledge, Taylor \& Francis Group.

Butler, T., and M. Savage, eds. 1995. Social change and the middle classes. London: UCL Press.

Callaghan, G., and P. Thompson. 2000. Proceeding to the paddling pool: The selection and shaping of call centre labour, Open University. Open Discussion Papers in Economics 15.

Casaca, S. 2005. Flexibilidade de Emprego, Novas Temporalidades de Trabalho e Relações de Género. A Reconfiguração da Desigualdade nos Novos Sectores dos Serviços. Lisboa. ISEG. Universidade Técnica de Lisboa. Dissertação de Doutoramento.

- 2006. La segregación sexual en el sector de las tecnologías de información y comunicación (TIC): observando el caso de Portugal. Sociología del Trabajo 57:95-130.

Castells, M. 1996; second edition 2009. The rise of network society. In Information age: Economy, society and culture, Vol. I. Malden, MA: Blackwell.

Dibben, P. 2004. Social movement unions. In Trade unions and democracy, ed. M. Harcourt, and G. Wood, 280-392. Manchester: Manchester University Press.

Drucker, P. 1959. Landmarks of tomorrow. New York, NY: Harper.

Eder, K. 1993. The new politics of class: Social movements and cultural dynamics in advanced societies. Londres: Sage Publications.

Edwards, R. 2001. Digital activism in the independent media center movement. Spectator 21 (2):82-94.

Esping-Andersen, G. 1993. Changing classes stratification and mobility in post-industrial societies. Newbury Park and Thousand Oaks: Sage Publications.

Estanque, E. 2005. Trabalho, Desigualdades Sociais e Sindicalismo. Revista Critica de Ciências Sociais 71:113-40. 
Estanque, E. 2010. Sindicalismo e movimentos sociais: Ação coletiva e regulação social no contexto europeu e português. Revista Lutas Sociais n 23. Revista do Núcleo de Estudos de Ideologia e Lutas Sociais da PUC. São Paulo.

Estanque, E., and A. Ferreira. 2002. Transformação no mundo laboral e novos desafios no sindicalismo português. Revista Crítica de Ciências Sociais 62: 151-9.

Eyerman, R., and A. Jamison. 1991. Social movements. A cognitive approach. Cambridge: Polity Press/Basil Blackwell.

Glucksmann, M. 2004. Call configurations: Varieties of call centre and divisions of labour. Work, Employment and Society 18 (4):795-811.

Habermas, J. 1998. O Discurso Filosófico da Modernidade. Lisboa: D. Quixote.

Hochschild, A. 1983. The managed heart: Commercialization of human feeling. Berkeley: University of California Press.

Huws, U. 2003. The making of a Cybertariat. Virtual work in a real world. Monthly Review Press. New York: The Merlin Press.

- 2014. Labor in the global digital economy: The Cybertariat comes of age. Montbly Review Press.

Keller, B., and H. Seifert. 2004. Flexicurity - The German trajectory. Transfer 10 (2):226-47.

Kosugi, R. 2008. Escape from work: Freelancing youth and the challenge to corporate fapan. Melbourne: Trans Pacific Press.

Kovács, I. 2002. As Metamorfoses do Emprego: Ilusões e Problemas da Sociedade de Informação. Oeiras: Celta Editora.

Kovács, I., and S. Casaca. 2004. Formas Flexíveis de Trabalho e Emprego no Sector das Tecnologias de Informação e Comunicação. V Congresso Portuguõs de Sociologia. Minho. Portugal.

Marx, K. 1990. Capital. A critique of political economy. Vol. 1 (trans. Ben Fowkes). London: Penguin Books.

Melucci, A. 1996. Challenging codes: Collective action in the information age. NewYork: Cambridge University Press.

Mukherjee, A., and N. Malhotra. 2006. Does role clarity explain employee-perceived service quality? A study of antecedents and consequences in call centres. International fournal of Service Industry Management 17(5): 444-473.

OECD. 1998. 21st Century technologies, promises and perils of a dynamic future. Paris: OECD Publishing.

Pannekoek, A. 1934. O Sindicalismo, http://www.marxists.org/portugues/pannekoe/1936/01.htm (acesso em 22-09-2007).

Parkin, F. 1968. Middle class radicalism: The social bases of the British campaign for nuclear disarmament. New York: Praeger.

Paugam, S. 2000. Le Salarié de la Précarité. Paris: PUF.

Paul, J., and U. Huws. 2002. 2nd draft report for the Tosca project. London: Analytica Social and Economic Research Ltd.

Pinto, A., P. Magalhães, L. Sousa, and E. Gorbunova. 2012. A qualidade da democracia em Portugal. A perspectiva dos cidadãos Workshop. The Quality of Democracy in Hard Times, ICS - UL, Lisbon.

Ribeiro, G. 2000. Política Cibercultural: ativismo político à distância na comunidade transnacional imaginadavirtual. In Cultura e Politica nos Movimentos Sociais Latino-Americanos, ed. S. Alverez, E. Dagnino, and A. Escobar, 465-502. Belo Horizonte: Editora UFMG.

Roque, I. 2010. As linhas de montagem teleoperacionais no mundo dos call centres. Coimbra: Faculdade de Economia a Universidade de Coimbra. Dissertação de Mestrado.

- 2016. Psychosocial risks at the Portuguese contact centres. In Occupational safety and bygiene IV, ed. Pedro M. Arezes, João Santos Baptista, Mónica P. Barroso, Paula Carneiro, Patrício Cordeiro, Nelson Costa, Rui B. Melo, A. Sérgio Miguel, Gonçalo Perestrelo, 615-21. London: CRC Press.

Scott, A. 1994. Gender segregation in the retail industr. In Gender segregation and social change. Men and women in changing labour markets. Alison MacEwen Scott (org.), 235-70. Oxford: Oxford University Press.

Sennett, R. 2001. The Corrosion of Character: The Personal Consequences of Work in the New Capitalism. New York: Routledge.

Standing, G. 2011. The Precariat: The new dangerous class. London. Bloomsbury Academic.

Taylor, P., and P. Bain. 1999. An assembly line in the head: Work and employee relations in the call centre. Industrial Relations Fournal. Oxford, UK: Blackwell Publishers.

- 2007. Reflections on the call centre: A reply to Glucksman. Work, Employment and Society 21 (2): 349-62.

Taylor, P., G. Mulvey, J. Hyman, and P. Bain. 2002. Work organisation, control and the experience of work in call centres. Work, Employment and Society 16 (1):133-50.

Taylor, S., and M. Tyler. 2000. Emotional labour and sexual difference in the airline industry. Work, Employment and Society 14 (2):77-95. 
Touraine, A. 1969. La société post-industrielle. Paris: Editions Denoël.

1984. Le Movement Ouvrier. Paris: Fayard.

1994. Crítica da Modernidade. Lisboa: Instituto Piaget.

Waterman, P. 2001. Trade union internationalism in the age of Seattle. Antípode, 33(3), 312-36.

- 2002. O internacionalismo sindical na era de Seattle. Revista Crítica de Ciências Sociais, 62, 33-68 (Coimbra; CES). 